\title{
The Effect of Simvastatin on Nitric Oxide and hs-CRP Levels in patients with Liver Cirrhosis at Dr. Moewardi Hospital, Surakarta
}

\author{
Budhi Hariyanto'), Paulus Kusnanto²), Bambang Purwanto²) \\ 1)Masters Program in Family Medicine, Universitas Sebelas Maret \\ ${ }^{2)}$ Departement of Internal Medicine, Faculty of Medicine, Universitas Sebelas Maret/ \\ Dr. Moewardi Hospital, Surakarta
}

\begin{abstract}
Background: The prevalence of liver cirrhosis $(\mathrm{SH})$ worldwide is at the seventh place as the cause of death. Increased pressure in the portal vein Portal Hypertension (HP) causes esophageal varices and the more likely the patient to bleed. Endothelial dysfunction in cirrhosis of the liver causes a decrease in nitric oxide (NO) levels resulting in an imbalance between relaxation factors and portal vein contractions and increasing hs-CRP levels. Simvastatin can increase NO levels and improve endothelial dysfunction in patients with $\mathrm{SH}$ and can reduce levels of hs-CRP. This study aimed determine the effect of simvastatin administration on nitric oxide and hs-CRP level in patients with liver cirrhosis.

Subjects and Method: This was a randomized controlled trial conducted at Dr. Moewardi hospital, Surakarta, Central Java. A sample of 29 patients was divided into treatment and control groups. 14 patients in treatment group were given simvastatin dose $20 \mathrm{mg} .15$ patients in control group received placebo. The dependent variable was nitric oxide and hs-CRP levels. The independent variable was Simvastatin administration. Nitric oxide serum level was measured by an enzyme linked immunosorbent assay (ELISA). Hs-CRP level was measured by immunechemiluminescent method. The data were analyzed by $t$ test.

Results: NO level after Simvastatin $20 \mathrm{mg}$ administration (Mean= $7.93 \mu \mathrm{g} / \mathrm{mL} ; \mathrm{SD}=1.78 \mu \mathrm{g} /$ $\mathrm{mL})$ was higher than before (Mean $=5.14 \mu \mathrm{g} / \mathrm{mL} ; \mathrm{SD}=2.25 \mu \mathrm{g} / \mathrm{mL}$ ) and it was statistically significant $(\mathrm{p}=0.001)$. Hs-CRP level after Simvastatin $20 \mathrm{mg}$ administration (Mean= 2.04 $\mathrm{mg} / \mathrm{L} ; \mathrm{SD}=0.80 \mathrm{mg} / \mathrm{L}$ ) was lowered than before $(\mathrm{Mean}=7.82 \mathrm{mg} / \mathrm{L} ; \mathrm{SD}=1.15 \mathrm{mg} / \mathrm{L})$ and it was statistically significant $(\mathrm{p}=0.001)$.

Conclusion: Simvastatin administration increases NO serum levels and reduce hs-CRP level in patients with liver cirrhosis.
\end{abstract}

Keywords: nitric oxide, hs-CRP, simvastatin, liver cirrhosis

\section{Correspondence:}

Budhi Hariyanto. Masters Program in Family Medicine, Universitas Sebelas Maret. Jl. Ir Sutami 36A, Surakarta 57126, Centra Java. Email: antohariyanto787@gmail.com. Mobile: 082328010442.

\section{BACKGROUND}

The prevalence of liver cirrhosis (SH) worldwide is at the seventh place as the cause of death. About 25,000 people die each year from this disease. The prevalence of $\mathrm{SH}$ disease can cause about 35,000 annual deaths in the United States (US) Cirrhosis is the ninth leading cause of death in the US and is responsible for 1$2 \%$ of all deaths in the US.
Many patients die in the fourth or fifth decade of their lives due to this disease (Bosch et al., 2003). There is no official national data on $\mathrm{SH}$ in Indonesia. But from some reports in government hospitals in Indonesia based on clinical course, it can be seen that the prevalence of $\mathrm{SH}$ treated in internal medicine generally ranges from 3.6 to $8.4 \%$ in Java and 
Sumatra, while Sulawesi and Kalimantan are under 1\% (Agus, 2007).

Some clinical and experimental studies have found endothelial dysfunction in cirrhosis of the liver as indicated by a decrease in NO levels. The cause of the decline in this level is still not clearly known, it is thought there is a connection with the hyperdynamic circulation and the presence of endotoxemia that is common in liver cirrhosis. Endothelial dysfunction can affect imbalances between factors of relaxation and contraction, between procoagulant mediators and anticoagulants or between substances that inhibit and promote growth. Biochemical markers commonly used for the determination of endothelial dysfunction as well as improvement in endothelial function, one of which is $\mathrm{NO}$ (Yu et al., 2000).

Another important thing is the finding that the use of simvastatin preparations can improve the function of eNOS. The use of statin preparations can increase NO levels and improve endothelial dysfunction in patients with $\mathrm{SH}$ and the use of statin preparations can reduce levels of hs-CRP (Ansell, 2003).

There are limitations to the use of conventional therapy with $\beta$-blockers and the unsatisfactory results with isosorbidmononitrate therapy as a replacement therapy so that the pleotropic effects of simvastatin are expected to contribute to therapy in the state of HP in patients with SH (Ritzel et al., 2002).

The number of HP events and the presence of disturbances in NO levels in SH patients, made the researchers focus this study on the effect of simvastatin on NO levels and hs-CRP levels in patients with SH.

\section{SUBJECTS AND METHOD \\ 1. Study Design}

This was a randomized controlled trial. A sample of 30 patients with liver cirrhosis divided into 15 patients with simvastatin $20 \mathrm{mg} /$ day and 15 patients with placebo. Samples of patients up to completion of the study were 29 patients divided into 14 patients with simvastatin and 15 patients with placebo.

This study was conducted in Department of Internal Medicine, Faculty of Medicine, Universitas Sebelas Maret/ Dr. Moewardi hospital, Surakarta, from July to November 2018. Samples taken were SH patients who routinely control each month at the Gastroenterohepatology Clinic as well as patients treated in the ward dr. Moewardi hospital Surakarta, which was taken randomly and fulfilled the inclusion and exclusion criteria and was willing to take part in the study by signing a blank agreement. Then the sample was divided into two groups, each of which consisted of 15 patients. Group I were patients given a placebo (control), group II were patients who were given simvastatin $20 \mathrm{mg}$ / day (therapy).

The dose of simvastatin given is 20 $\mathrm{mg} /$ day. Blood collection techniques and handling of specimens where NO and hsCRP tests were performed both before and after the treatment. NO examination was carried out by taking blood samples through the antecubital vein with a quiet room with controlled temperature (24$25^{\circ} \mathrm{C}$ ), blood taken with a $3 \mathrm{cc}$ citrate tube and then alternating slowly 10 times until homogeneous. Centrifug $3000 \mathrm{~g}$ for 10 minutes, immediately separate the plasma into 3 cup samples @0.3 cc of plasma. Enter the identity, name, date and type of examination. Store at -20 oC (3 months stability). Blood processing and NO checks are carried out in collaboration with Prodia Clinical Laboratories. The 
reagent kit used for Nitrate/Nitrite Colorimetric Assay is a product of the Cayman Chemical Company, Ann Arbor, MI 48108, USA, Cat: 780001 , Lot: 0458197.

On HsCRP examination (Immunochemiluminescent Method): Diluted samples, ligand labeled anti-CRP monoclonal antibodies were included in the unit test containing anti-ligand, and incubated for 30 minutes at $37 \mathrm{C}$ with occasional shaking. During shaking, CRP in the sample forms a sandwich antibody complex that binds to the anti-ligand in the solid phase. The non-bonded conjugate was removed in spinning washing, then added the substrate and the test unit was incubated for 10 minutes. Chemiluminescent substrates, phosphate esters of adamantyldioxetan, undergo hydrolysis in the presence of alkaline phosphatase produce continuous light emission, thus improving precision by providing multiple reading windows. The complex bonds and photons produced, measured by luminosity are proportional to the CRP concentration in the sample.

\section{RESULTS}

Simvastatin significantly increaseserum NO levels $($ Mean $=7.93 \mu \mathrm{g} / \mathrm{mL} ; \mathrm{SD}=1.78$ $\mu \mathrm{g} / \mathrm{mL})$ than before $($ Mean $=5.14 \mu \mathrm{g} / \mathrm{mL}$; $\mathrm{SD}=2.55 \mu \mathrm{g} / \mathrm{mL}$ ) and it was statistically significant $\quad(p=0.001)$ Simvastatin decreased hs-CRP levels (Mean $=2.04$ $\mathrm{mg} / \mathrm{L} ; \quad \mathrm{SD}=0.80 \mathrm{mg} / \mathrm{L}$ ) than before $($ Mean $=7.82 \mathrm{mg} / \mathrm{L} ; \mathrm{SD}=1.15 \mathrm{mg} / \mathrm{L})$ and it was statistically significant $(\mathrm{p}=0.001)$.

Table 1. The results of $t$ test

\begin{tabular}{lccccc}
\hline \multicolumn{1}{c}{$\begin{array}{c}\text { Independent } \\
\text { Variables }\end{array}$} & \multicolumn{2}{c}{ Treatment } & \multicolumn{2}{c}{ Control } & \multirow{2}{*}{ p } \\
\cline { 2 - 5 } & Mean & SD & Mean & SD & 0.847 \\
SGOT & 88.64 & 78.50 & 106.93 & 94.79 & 0.331 \\
SGPT & 153.07 & 45.66 & 56.80 & 52.59 & 0.949 \\
Ureum & 53.07 & 45.66 & 52.67 & 39.35 & 0.767 \\
Kreatinin & 1.17 & 0.29 & 1.22 & 0.54 & 0.464 \\
Albumin & 3.09 & 0.73 & 2.91 & 0.56 & 0.477 \\
Bilirubin1 & 1.04 & 0.69 & 0.84 & 0.47 & 0.377 \\
Bilirubin2 & 0.66 & 0.40 & 0.76 & 0.49 & 0.847 \\
Bilirubin total & 1.70 & 1.06 & 1.60 & 0.85 & 0.474 \\
PT & 15.81 & 1.85 & 16.73 & 4.35 & 0.591 \\
INR & 1.29 & 0.30 & 1.40 & 0.51 & 0.774 \\
CN_test & 93.79 & 21.81 & 91.00 & 29.19 & \\
\hline
\end{tabular}

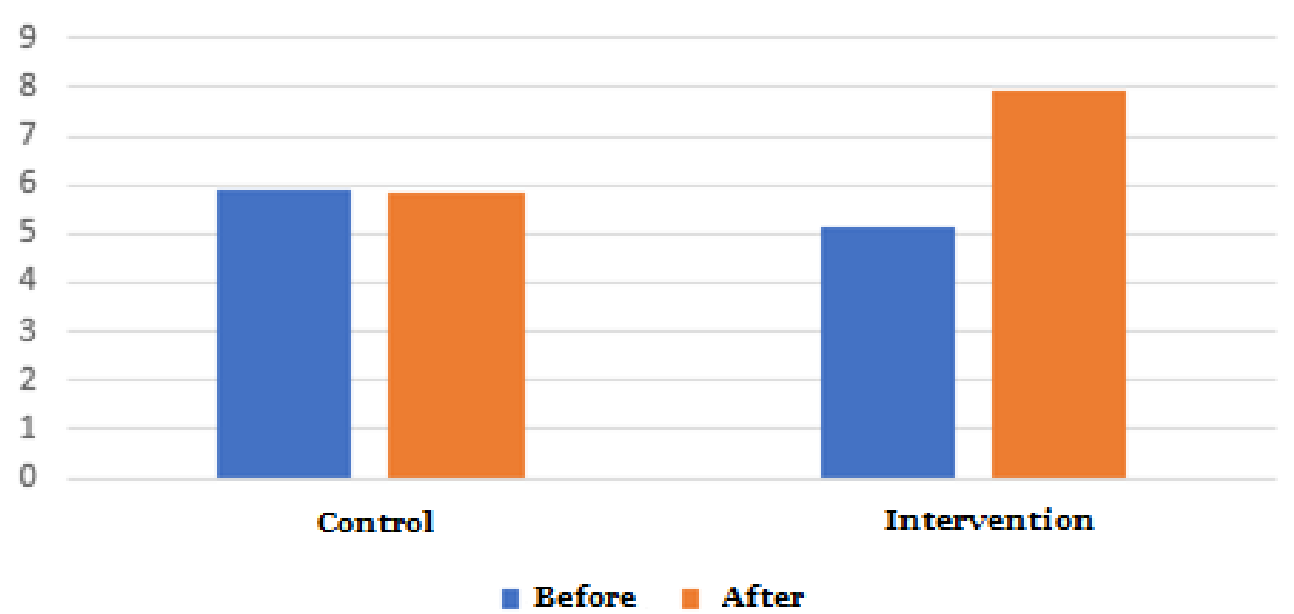

Figure 1. Nitric Oxide Level between Treatment and Control Groups 


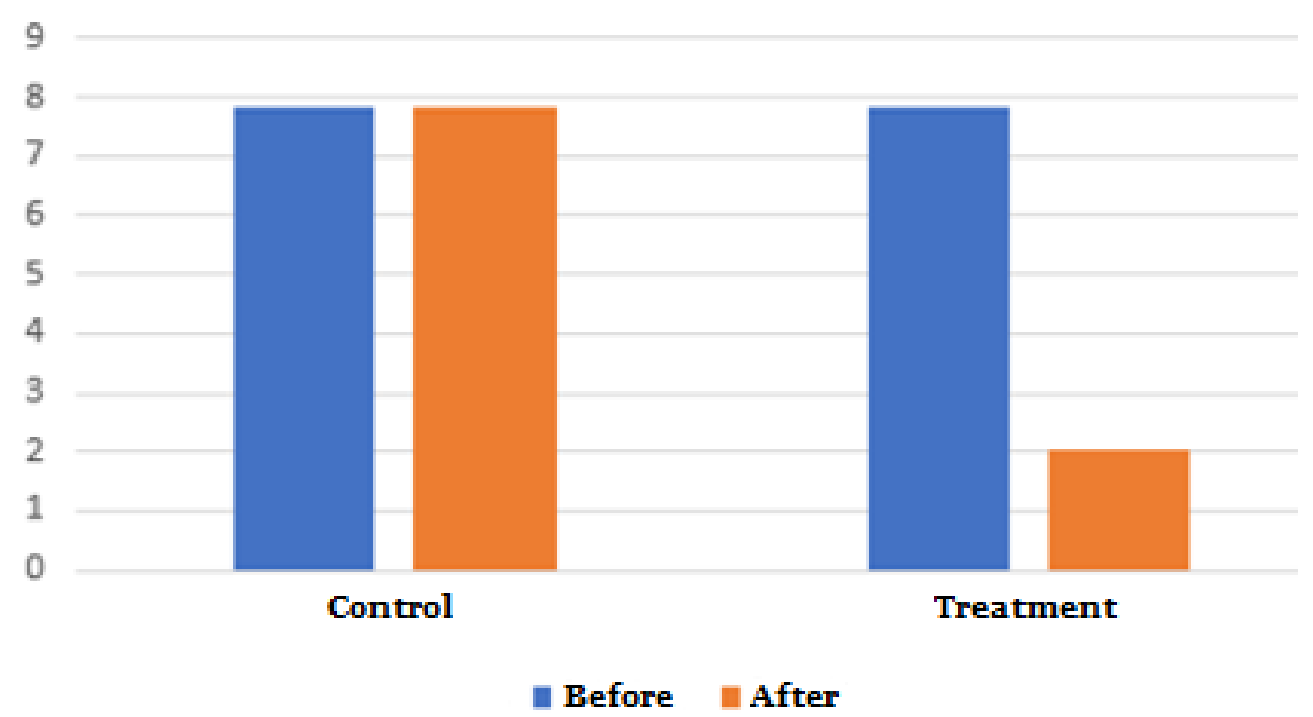

Figure 2. Hs-CRP Level between Treatment and Control Groups

Table 2.The Result of Analysis of 2 Mean Difference Test

\begin{tabular}{lcccccc}
\hline \multirow{2}{*}{ Independent Variables } & \multicolumn{2}{c}{ Before } & \multicolumn{2}{c}{ After } & \multirow{2}{*}{ p } \\
\cline { 2 - 5 } & \multicolumn{1}{c}{ Mean } & SD & Mean & SD & 0.001 \\
NO & 5.14 & 2.55 & 7.93 & 1.78 & 0.001 \\
Hs-CRP & 7.82 & 1.15 & 2.04 & 0.80 & 0.001 \\
\hline
\end{tabular}

\section{DISCUSSION}

This study showed that the treatment group experienced a significant increase in nitric oxide (NO) compared to the control group and the administration of simvastatin could increase NO levels in liver cirrhosis. This condition was caused by liver cirrhosis portal hypertension (HP) which would act as an Associated Molecular Pattern (DAMP) Damage which would be captured by the Antigen Processing and Presenting Cell (APC) through the TollLike Receptor-9 (TLR 9) pathway and would be presented through MHC II, this incident would change the balance on Th1 which would produce Colony Stimulating Factor (CSF) and Interferon- $\gamma$ (IFNү). CSF would activate neutrophils, and IFN- $\gamma$ would activate macrophages to secrete pro-inflammatory cytokines such as TNF- $\alpha$, Interleukin (IL-1, IL-6, and IL8). This condition was the incidence of low grade inflammation in liver cirrhosis and can cause endothelial dysfunction (Guntur, 2008), endothelial dysfunction would trigger oxidative stress resulting in decreased production of nitric oxide levels (Rajat et al.,2003).

The administration of simvastatin in treated patients significantly increased NO levels because it would inhibit Rho geranylgeranylation and thus trigger the stability of eNOS mRNA and simvastatin triggered upregulation of eNOS (Laufs et al., 2000). According to research, statins have the ability of anti-oxidants so that they were capable of being inhibitors of $\kappa \beta$ kinase (IKK) so that NFk $\beta$ activation was inhibited and triggers a decrease in oxidative stress (Guntur, 2008). Simvastatin also decreased Rac1's membrane under basal conditions thereby reducing angiotensin II. A decrease in angiotensin II would reduce the activation of Angioten$\sin 1$ receptors (AT1) and reduce Reactive Oxygen Species ROS in vitro and in vivo (Diez et al., 2010). Statins would improve 
endothelial dysfunction due to oxidative stress and increase NO in various ways (Suciu, 2009). Trocha et al. (2010) also reported that simvastatin would increase eNOS. This study showed that the treatment group had a tendency to decrease hs-CRP levels compared to the control group.

There was study that was in line with this study regarding the use of simvastatin preparations which have antioxidant ability so that they were capable of inhibiting $\kappa \beta$ kinase (IKK) to decrease oxidative stress. Simvastatin also decreased Rac1 membrane under basal conditions thereby reducing angiotensin II. A decrease in angiotensin II would reduce the activation of Angiotensin 1 receptors (AT1) and reduce Reactive Oxygen Species ROS in vitro and in vivo (Diez et al., 2010).

Suciu (2009) stated that statins would improve endothelial dysfunction due to oxidative stress and reduce hs-CRP levels in various ways. Wright et al. (2014) stated that simvastatin would increase eNOS which lead to an increase in NO.

The effect of NO vasodilation was expected to reduce hs-CRP levels. Therefore, the administration of Statins (3Hydroxy-3-methylglutary-co-enzyme A reductase inhibitors) can reduce intrahepatic vascular resistance and improve hepatic blood flow in the presence of vasodilation in liver cirrhosis. This was mediated by an increase in NO production due to improved vascular endothelium by increasing endothelial Nitric Oxide Syntase (eNOS). It was expected that statins can repair endothelium in liver tissue for NO production, so that these preparations can be used as selective vasodilators of portal hypertension in liver cirrhosis (Francoz et al.,2010).

This study aimed to investigate a relationship between changes in NO levels and hsCRP levels in the treatment with simvastatin supplementation. The results of the study indicated that there was a negative relationship between the NO variable and the hs-CRP level variable significantly. It can be interpreted that if the NO variable was improved or has increased, the tendency of hs-CRP tends to decrease which mean that improvement in port hypertension has occurred, this was in accordance with the study of Wiest et al. CRP resulting in portal venous vasodilation and improvement of portal hypertension in liver cirrhosis.

\section{REFERENCES}

Abraldes JG, Rodriguez-Vilarrupla A, Graupera M (2007). Simvastatin treatment improves liver sinusoidal endothelial dysfunction in $\mathrm{CCl}_{4}$ cirrhotic rats. J Hepatol.46: 10401046.

Dahlan MS (2009). Menggunakan rumus besar sampel secara benar. Dalam: Dewi J (ed). Besar sampel dan cara pengambilan sampel dalam penelitian kedokteran dan kesehatan. Salemba Medika. Jakarta. Edisi 2.

Diez RR, Raquel RD, Lavoz C, Mateos SR, Civantos E, Vita JR, et al. Statins Inhibit Angiotensin II/Smad Pathway and Related Vascular Fibrosis, by a TGF-b-Independent Process. PLoS ONE 5(11): e14145. https://doi.org/10.1371/journal.pone.00141 45 .

Franchis R (2005). Evolving. Consensus In Portal Hypertension Report Of The Baveno IV Consensus Workshop On Methodology Of Diagnosis And Therapy In Portal Hypertension. J Hepatol. 43: 167-176.

FrancozC,Glotz D, Moreau R, Durand F (2010). The evaluation of renal function and disease in patients with cirrhosis.Journal of Hepatology. (52): 605-613 
Indonesian Journal of Medicine (2019), 4(1): 9-14

https://doi.org/10.26911/theijmed.2019.04.01.02

Gulberg V, Moller S, Gerbes A, Henriksen JH (2000). Increased Renal production of Natriuretic Peptide (CNP) in Patients with Cirrhosis and Functional Renal Failure. Gut. 47:852857.

Guntur HA (2008). SIRS, sepsis dan syok septic imunologi, diagnosis dan penatalaksanaan). Dalam: Guntur. Perspektif masa depan imunologiinfeksi. Sebelas Maret University Press. Surakarta.

Garcia-Pagan JC, Feu F, Bosch J, et al. (2001). Propranolol compared with propranolol plus isosorbide-5mononitrate for portal hypertension incirrhosis. A randomized controlled study. Ann Intern Med. 114: 869873.

Laufs U, Liao JK (2000). Vascular Effects of HMG-CoA Reductase Inhibitors Trends in Cardiovascular. Medicine. 10(4): 143-148.

Mason JC (2003). Statins And Their Role In Vascular Protection. Clinical Science. 105: 251-266.

Rajat SB, Ambrose JA, Srivastava S, DeVoe MC, Reynolds LJE. Direct (2003). Reactive Oxygen Species Are
Involved in Smoking-Induced Dysfunction of Nitric Oxide Biosynthesis and Up-regulation of Endothelial Nitric Oxide Synthase An In Vitro Demonstration in Human Coronary Artery Endothelial Cells. Circulation. (107): 2342-2347.

Santjaka A (2011). Teknik sampling. dalam: Sigit H, Abay F (editors). Statistik untuk penelitian kesehatan. Nuha Medika. Yogyakarta. Edisi I.

Suciu M (2009). The role of nitric oxide (NO) and statins in endothelial dysfunction and atherosclerosis. Farmacia. 57(2): 131-140.

Trocha M, Anna ML, Szuba A, Chlebda E, Piesniewska M, Sozañski T, et al (2010). Effect of simvastatin on nitric oxide synthases (eNOS, iNOS) and arginine and its derivatives (ADMA, SDMA) in ischemia/reperfusion injury in rat liver.Pharmacological Reports. 62:343-351.

Zhang Z, Wang M, Xue SJ, Liu DH, Tang YB (2012). Simvastatin Ameliorates Angiotensin II-Induced Endothelial Dysfunction Through Restoration of Rho-BH4-eNOS-NO Pathway. Cardiovasc Drugs Ther. 26(1): 31-40. 